\title{
Ecografia renovezicală la copiii cu infecții de tract urinar
}

\author{
Gabriel C. Drăgan \\ Secţia Chirurgie Pediatrică, Spitalul Clinic de Copii „Dr. Victor Gomoiu“, Bucureşti
}

\begin{abstract}
REZUMAT
Introducere. Infecţiile de tract urinar (ITU) sunt o problemă frecventă în rândul pacienţilor de vârstă pediatrică. Ele pot reprezenta primul semn al unor anomalii congenitale ale tractului urinar la pacienţii cu vârsta sub 2 ani, refluxul vezicoureteral (RVU) fiind cea mai întâlnită anomalie. Ecografia renovezicală este cea mai utilizată investigaţie imagistică la copiii cu ITU. Ecografia renovezicală este noninvazivă, neiradiantă şi cea mai ieftină investigaţie.

Materiale şi metode. Studiul de faţă este o analiză retrospectivă a pacienţilor internaţi pentru ITU în Spitalul Clinic pentru Copii „Grigore Alexandrescu“ din Bucureşti, în perioada 1 ianuarie 2015-31 decembrie 2017. Rezultate. Ecografia renovezicală a fost efectuată în 310/359 cazuri. Anomaliile de tract urinar au fost depistate la 108 pacienţi. În 67/108 de cazuri au fost identificate dilataţii ale tractului urinar superior. 31/191 de pacienţi $(16 \%)$ cu vârsta sub 2 ani au avut dilataţii ale tractului urinar la ecografie, în timp ce la 36/119 (30\%) de cazuri cu vârsta peste 2 ani au fost depistate aceste modificări. La 61 de cazuri au fost disponibile atât ecografia renovezicală, cât şi cistografia micţională. 11/29 pacienţi cu dilataţii ale tractului urinar superior la ecografie au fost diagnosticaţi cu RVU la cistografie (8 pacienţi cu RVU de grad mare). 8 pacienţi cu ecografii renovezicale normale au fost diagnosticaţi cu RVU la cistografie (5 pacienţi cu RVU de grad mare).

Concluzii. Deşi ecografia renovezicală este noninvazivă şi neiradiantă, valoarea ei, când este utilizată fără alte investigaţii complementare, în diagnosticarea anomaliilor congenitale de tract urinar la copiii cu ITU, în special RVU, este limitată.
\end{abstract}

Cuvinte cheie: infecţie de tract urinar, copii, ecografie

\section{INTRODUCERE}

Infecţiile de tract urinar (ITU) reprezintă o problemă frecventă în rândul pacienţilor pediatrici $(1,2)$. Prevalenţa este estimată la $7-10 \%$ în rândul copiilor cu vârsta sub 2 ani cu febră fără o cauză aparentă. Aceasta şi manifestările clinice sunt influenţate de vârsta şi sexul pacienţilor. Astfel, incidenţa este mai mare în rândul băieţilor în primele 6 luni de viaţă, ulterior aceasta fiind mai mare în rândul fetelor (1,3). ITU au morbiditate ridicată şi pot conduce la complicaţii pe termen lung, precum cicatricile renale, hipertensiune arterială şi boală renală cronică (BRC) (4). Ele pot reprezenta primul semn al unor anomalii congenitale ale rinichiului sau ale tractului urinar la copiii cu vârsta sub 2 ani, refluxul vezicoureteral (RVU) fiind cea mai întâlnită anomalie (5). ITU recidivante şi riscul apariţiei cicatricilor renale şi al BRC reprezintă o indicaţie pentru diagnosticul şi tratamentul ITU şi al eventualelor anomalii renale sau de tract urinar $(1,5,6)$.
Investigaţiile imagistice ale tractului urinar la copiii cu ITU depistează anomalii congenitale ale tractului urinar în $20-80 \%$ dintre cazuri (3). Pe de altă parte, impactul diagnosticării unei anomalii congenitale în urma unei ITU nu este foarte bine studiat. Diagnosticul acestor anomalii este rezonabil doar dacă tratamentul acestora poate reduce semnificativ incidenţa ITU şi a complicaţiilor lor (7).

Ecografia renovezicală este cea mai utilizată investigaţie imagistică la copiii cu ITU. Este o investigaţie noninvazivă, neiradiantă şi cea mai ieftină dintre investigaţiile disponibile. Ecografia renovezicală oferă informaţii importante despre dimensiunile şi forma rinichilor, precum şi despre prezenţa dilataţiilor tractului urinar. Ecografia renovezicală poate identifica, de asemenea, abcese renale sau perirenale, precum şi pionefroza la copiii cu ITU cu evoluţie nefavorabilă sub tratament antibiotic $(8,9,10)$. 
Deşi ecografia renovezicală poate fi o investigaţie utilă în diagnosticarea anomaliilor structurale ale aparatului renourinar, utilizarea doar a ecografiei renovezicale în evaluarea copiilor cu ITU febrile nu este recomandată, aproximativ o treime dintre pacienţii cu RVU de grad mic nefiind diagnosticaţi corect $(3,8)$.

Scopul acestui studiu este de a evalua valoarea ecografiei renovezicale ca metodă de a investiga tractul urinar la copiii cu ITU.

\section{MATERIALE ŞI METODE}

Studiul de faţă este o analiză retrospectivă a pacienţilor internaţi pentru ITU în Spitalul Clinic de Urgenţă pentru Copii „Grigore Alexandrescu“ din Bucureşti în perioada 1 ianuarie 2015-31 decembrie 2017.

Criteriile de includere au fost vârsta sub 18 ani şi diagnosticul de infecţie de tract urinar. Copiii diagnosticaţi anterior $\mathrm{cu}$ anomalii ale tractului urinar au fost excluşi.

Datele au fost colectate din sistemul informatic al spitalului şi au fost analizate cu Microsoft ${ }^{\circledR}$ Excel (ver. 16.15) şi IBM ${ }^{\circledR}$ SPSS ${ }^{\circledR}$ Statistics (ver. 25).

\section{REZULTATE}

În perioada 1 ianuarie 2015-31 decembrie 2017 au fost internaţi 826 de pacienţi pentru suspiciunea de ITU. Dintre aceştia, 359 au fost incluşi în studiu (ITU confirmată sau probabilă). Au fost 211 fete $(58,8 \%)$. Vârsta medie a fost 44,76 luni, cu un minim de 4 zile şi un maxim de 17,9 ani.

227 au avut vârsta la internare sub 2 ani, 111 fete şi 116 băieţi. În grupul pacienţilor cu vârsta mai mare de 2 ani au fost 132 de pacienţi, 100 de fete şi 32 de băieţi $(\mathrm{p}<0,001)$ (Figura 1$)$.

Ecografia renovezicală a fost efectuată în 310 cazuri. Anomaliile de tract urinar au fost depistate la 108 pacienţi. La 41 de cazuri au fost depistate doar anomalii ale vezicii urinare (îngroşare a peretelui vezical sau sediment vezical). La celelalte 67 de cazuri au fost identificate dilataţii ale tractului urinar (44 de cazuri de dilataţii pielocaliceale, 17 cazuri de dilataţii pielocaliceale şi ureterale şi 6 cazuri de dilataţii ureterale) (Figura 2).

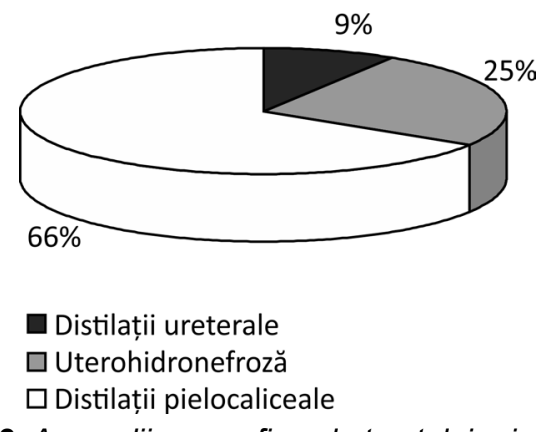

FIGURA 2. Anomalii ecografice ale tractului urinar

59/184 de fete (32\%), respectiv 49/126 de băieţi $(39 \%)$ au avut o ecografie renovezicală pozitivă

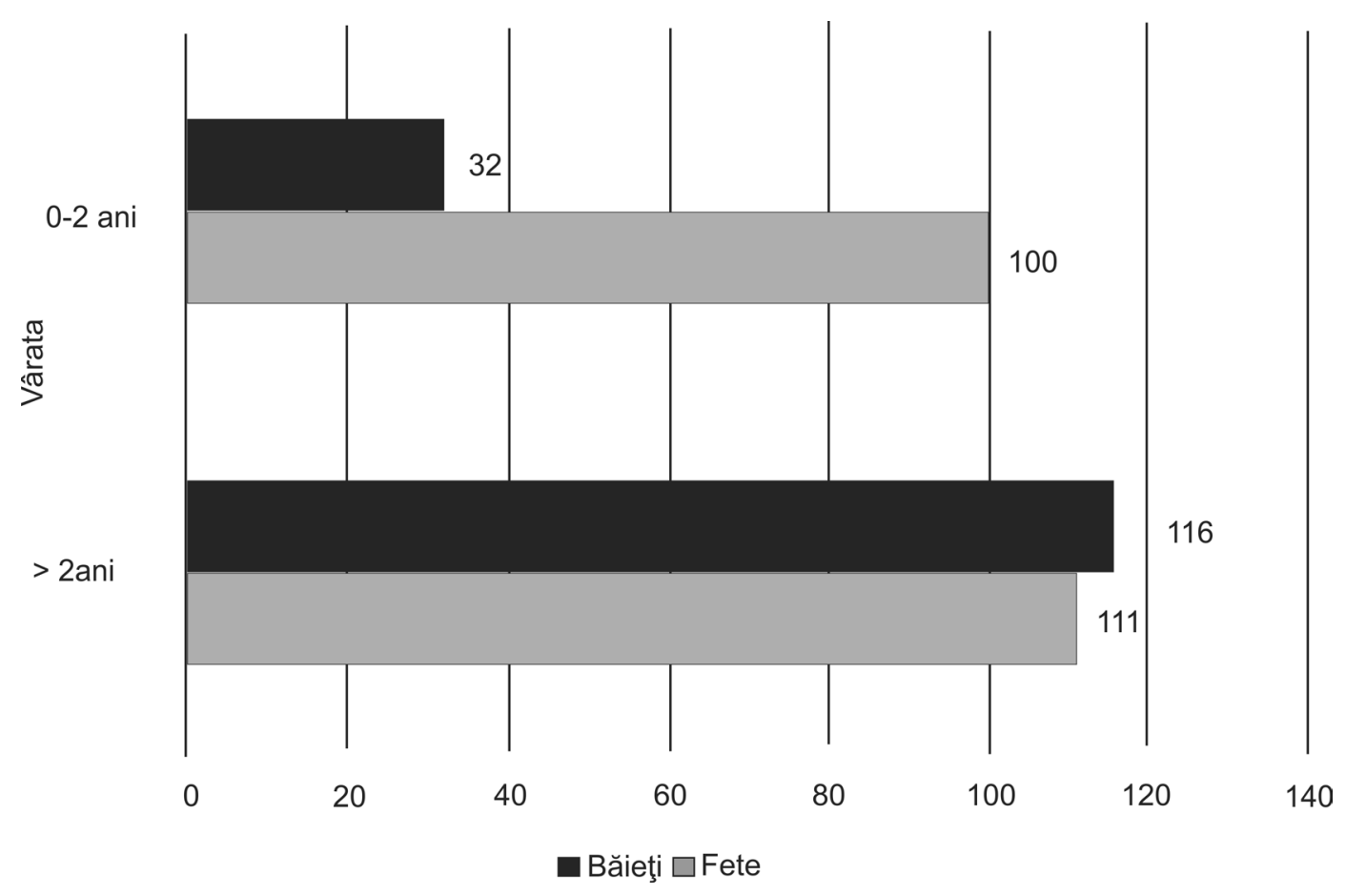

FIGURA 1. Distribuția pe sexe în funcție de vârstă 
(p>0,05). 31/191 de pacienţi (16\%) cu vârsta sub 2 ani au avut dilataţii ale tractului urinar superior, respectiv 36/119 de pacienţi (30\%) cu vârsta peste 2 ani $(\mathrm{p}<0,05)($ Tabelul 1).

TABELUL 1. Rezultatele ecografiei renovezicale în funcție de vârstă

\begin{tabular}{|l|c|c|c|c|}
\hline \multicolumn{2}{|c|}{} & \multicolumn{2}{|c|}{ Ecografie renovezicală } & \multirow{2}{*}{ Total } \\
\cline { 2 - 4 } \multicolumn{2}{|c|}{} & Normală & $\begin{array}{c}\text { Dilatații de tract } \\
\text { urinar superior }\end{array}$ & \\
\hline \multirow{2}{*}{ Vârsta } & $\mathbf{0 - 2}$ ani & 160 & 31 & 191 \\
\cline { 2 - 5 } & $>\mathbf{2}$ ani & 83 & 36 & 119 \\
\hline \multicolumn{2}{|l|}{ Total } & 243 & 67 & 310 \\
\hline
\end{tabular}

Cistografia micţională a fost efectuată în 66 de cazuri. La 61 de cazuri, atât ecografia, cât şi cistografia au fost disponibile studiului. 11/29 pacienţi cu dilataţii ale tractului urinar superior la ecografie au fost diagnosticaţi cu reflux vezicoureteral la cistografie ( 8 pacienţi cu RVU de grad mare). 8 pacienţi cu ecografie renovezicală normală au fost diagnosticaţi cu RVU la cistografie (5 pacienţi cu RVU de grad mare) $(p>0,05)$ (Tabel 2).

TABELUL 2. Rezultatele ecografiei renovezicale în funcție de gradul de reflux vezicoureteral

\begin{tabular}{|c|c|c|c|c|c|}
\hline & \multicolumn{3}{|c|}{ Reflux vezicoureteral } & \multirow[b]{2}{*}{ Total } \\
\hline & & $\begin{array}{l}\text { Fără } \\
\text { RVU }\end{array}$ & $\begin{array}{c}\text { RVU } \\
\text { grad I-II }\end{array}$ & $\begin{array}{c}\text { RVU grad } \\
\text { III-V }\end{array}$ & \\
\hline \multirow[b]{2}{*}{$\begin{array}{l}\text { Ecografie } \\
\text { renovezicală }\end{array}$} & Normal & 24 & 3 & 5 & 32 \\
\hline & $\begin{array}{l}\text { Dilatații de } \\
\text { tract urinar } \\
\text { superior }\end{array}$ & 18 & 3 & 8 & 29 \\
\hline \multicolumn{2}{|l|}{ Total } & 42 & 6 & 13 & 61 \\
\hline
\end{tabular}

\section{DISCUṬII}

Ecografia renovezicală este cel mai frecvent utilizată investigaţie imagistică la copiii cu ITU, deşi valoarea ei este intens dezbătută, aceasta având sensibilitate şi specificitate reduse în diagnosticul anomaliilor congenitale renale şi ale tractului urinar. În 2011, Asociaţia Americană de Pediatrie recomanda ecografia renovezicală în cazul tuturor pacienţilor sub 2 ani cu ITU (11). Ghidul NICE (The National Institute of Health and Care Excellence) din 2007 (actualizat în 2013 şi 2017) recomandă ecografia renovezicală doar în cazuri selecţionate de pacienţi cu ITU (ITU cu bacterii non-Escherichia coli, evoluţie nefavorabilă sub tratament antibiotic, vârsta sub 6 luni) (12). În studiul de faţă, ecografia a fost efectuată la $86 \%$ dintre pacienţi şi a fost normală în $65 \%$ dintre cazuri. Dilataţiile de tract urinar superior care conduc la schimbarea managementului pacientului (necesitatea completării diagnosticului cu alte metode ima- gistice sau a monitorizării ecografice) au fost depistate la $21 \%$ dintre cazuri (67/310 pacienţi). Aceste date confirmă rezultatele lui Preda et al., care au descoperit o incidenţă de $41 \%$ a anomaliilor de tract urinar la copiii cu ITU (13). Suson et al. au raportat o incidenţă similară (14), în timp ce Nelson et al. au raportat o incidenţă mai mică, de doar $25 \%$ a anomaliilor de tract urinar depistate ecografic la pacienţii cu ITU (15).

Dacă în funcţie de sexul pacienţilor nu au existat diferenţe semnificative statistic în ceea ce priveşte modificările ecografice, am constatat o diferenţă semnificativă între pacienţii cu vârsta sub sau peste 2 ani. Deşi majoritatea studiilor raportează o incidență crescută a anomaliilor congenitale de tract urinar la copiii cu vârsta sub 2 ani cu ITU $(5,11)$, în studiul de faţă am observat că majoritatea anomaliilor de tract urinar au fost observate la copiii cu vârsta peste 2 ani. Aceste rezultate pot fi explicate prin excluderea din studiu a pacienţilor diagnosticaţi anterior cu anomalii de tract urinar, inclusiv a celor diagnosticaţi antenatal. Acest lucru duce la o creştere a numărului copiilor cu anomalii de tract urinar ce sunt diagnosticaţi mai târziu, cu ocazia unei ITU.

Am analizat valoarea ecografiei în identificarea pacienţilor cu RVU. A fost un număr ridicat de pacienţi cu ecografie renovezicală normală diagnosticaţi ulterior cu RVU la cistografie, inclusiv 5 pacienţi $(16 \%)$ cu RVU de grad mare (III-V). Deşi rezultatele nu sunt semnificative statistic având în vedere lotul mic de pacienţi, numărul pacienţilor care ar beneficia de corecţia RVU şi care nu au fost diagnosticaţi în urma ecografiei renovezicale este mare. Astfel, putem sugera că ecografia renovezicală are o valoare limitată în identificarea pacienţilor cu RVU.

Limitele studiului de faţă sunt reprezentate de natura retrospectivă şi observaţională a acestuia. $\mathrm{O}$ altă limită a studiului este numărul de pacienţi incluşi. Deşi datele obţinute sunt comparabile cu alte studii asemănătoare, numărul pacienţilor cu modificări ecografice este redus, semnificaţia statistică a rezultatelor fiind astfel, de asemenea, redusă. De asemenea, ecografia renovezicală este o investigaţie subiectivă, dependentă de operator. Deşi toate investigaţiile au fost efectuate de medici radiologi cu experienţă în patologia pediatrică, acest neajuns al ecografiei nu poate fi exclus.

\section{CONCLUZII}

Deşi ecografia renovezicală este o investigaţie noninvazivă şi neiradiantă, valoarea ei când este 
utilizată fără alte investigaţii este limitată în diagnosticarea anomaliilor congenitale de tract urinar, în special a RVU. Recomandăm utilizarea complementară a investigaţiilor imagistice la pacienţi se-

\section{BIBLIOGRAFIE}

1. Prajapati H. Urinary tract infections in children. Paediatr. Child Heal. (United Kingdom). 2018;28:318-323.

2. Copp HL, Schmidt B. Work up of pediatric urinary tract infection. Urol Clin North Am. 2015;42:519-526.

3. Hannula A, Venhola M, Perhomaa M et al. Imaging the urinary tract in children with urinary tract infection. 2012;100.

4. Madhi $\mathrm{F}$ et al. Febrile urinary-tract infection due to extendedspectrum beta-lactamase-producing Enterobacteriaceae in children: A French prospective multicenter study. PLoS One. 2018; 13:1-14.

5. Okarska-Napierała M, Wasilewska A, Kuchar E. Urinary tract infection in children: Diagnosis, treatment, imaging - Comparison of current guidelines. J. Pediatr. Urol. 2017;13:567-573.

6. Palacios Loro ML, Segura Ramirez DK, Ordonez Alvarez FA et al. Congenital anomalies of the kidney and urinary tract. A vision for the paediatrician. An Pediatr (Barc). 2015;83:442e1-442e5.

7. Vachvanichsanong P, Dissaneewate P, McNeil E. What Did We Find From Imaging Studies in Childhood Urinary Tract Infection and Which Studies Are Mandatory?. Urology. 2018;111:176-182.

8. Tsai I. The Role of Renal Ultrasound in Children with Febrile Urinary Tract Infection. Pediatr. Neonatol. 2016;57:83-84.

9. Ghobrial EE, Abdelaziz DM, Sheba MF et al. Value of Ultrasound in Detecting Urinary Tract Anomalies after First Febrile Urinary Tract Infection in Children. Clin. Pediatr. (Phila). 2015;55:415-420. lectaţi pentru diagnosticul anomaliilor de tract urinar. Sunt necesare studii pe loturi mai mari de pacienţi pentru a stabili corelaţia între investigaţiile imagistice şi copiii cu ITU.

Conflict of interest: none declared Financial support: none declared

10. Jadresic L. Urinary tract infections in children. Paediatrics and child health. 2014;24:289-292.

11. Subcommittee on Urinary Tract Infection, Steering Committee on Quality Improvement and Management, Roberts KB. Urinary tract infection: clinical practice guideline for the diagnosis and management of the initial UTI in febrile infants and children 2 to 24 months. Pediatrics. 2011;128:595-610.

12. National Institute for Health and Care Excellence. Urinary tract infection in children: diagnosis, treatment and long-term management. 2007.

13. Preda I, Jodal U, Sixt $R$ et al. Value of Ultrasound in Evaluation of Infants With First Urinary Tract Infection. JURO. 2010;183:1984-1988.

14. Suson KD, Mathews R. Evaluation of children with urinary tract infection - Impact of the 2011 AAP guidelines on the diagnosis of vesicoureteral reflux using a historical series. J. Pediatr. Urol. 2014;10:182-185.

15. Nelson C, Chow J, Johnson E et al. Test characteristics and predictive value of ultrasound as a screening test for $\mathrm{GU}$ anomalies among children presenting with UTI. J. Urol. 2013;189:266. 